\title{
The influence of adipose-derived stromal vascular fraction cells on the treatment of knee osteoarthritis
}

Masanori Tsubosaka ${ }^{1,2}$, Tomoyuki Matsumoto', Satoshi Sobajima2, Takehiko Matsushita', Hideki Iwaguro² and Ryosuke Kuroda ${ }^{1}$

\begin{abstract}
Background: Adipose-derived stromal vascular fraction (SVF) cells are a mixed cell population that includes cells with multilineage potential, similar to bone marrow-derived mesenchymal stem cells. Our purpose is to investigate the influence of SVF cells in patients with knee osteoarthritis $(O A)$ and the short-term treatment effects.

Methods: Fifty-seven patients were enrolled and treated with intra-articular injection of $2.5 \times 10^{7}$ SVF cells into the knee joint between September 2017 and March 2018. All patients were followed up for 12 months or longer. Mean age at treatment and follow-up period were $69.4 \pm 6.9$ years and $13.7 \pm 2.0$ months, respectively. The mean preoperative hip-knee-ankle angle was $6.7 \pm 3.6^{\circ}$. SVF cells were prepared using the Celution ${ }^{\circledR} 800 / C R S$ system from the patients' abdominal or breech subcutaneous fat. The mean SVF cell viability was $90.6 \pm 2.7 \%$. Clinical evaluations were performed for range of motion, Western Ontario and McMaster Universities Osteoarthritis Index (WOMAC), visual analog scale (VAS) for pain, and the Knee injury and Osteoarthritis Score (KOOS). Imaging evaluations, which included the hip-knee-ankle angle assessed via radiography, and T2 mapping value using a 1.5-T magnetic resonance imaging unit were also assessed. Both clinical and imaging evaluations were performed preoperatively, 1 , 3,6 , and 12 months postoperatively, and compared among all timepoints $(p<0.05)$.
\end{abstract}

Results: Knee extension angle at 6 and 12 months postoperatively was significantly better than the preoperative angle. Total WOMAC, VAS, and KOOS scores at 1, 3, 6 and 12 months postoperatively were significantly better than preoperative scores. There was no significant difference in hip-knee-ankle angle among the five time periods. T2 mapping values of lateral femur and tibia were significantly higher 12 months postoperatively than preoperatively.

Conclusions: The short-term clinical effects of intra-articular SVF cell injection on knee OA were excellent. Intraarticular SVF cell injection is a novel and innovative approach for treating patients with knee OA.

Keywords: Adipose-derived stromal vascular fraction cells, Stem cell, Osteoarthritis, T2 mapping

\footnotetext{
* Correspondence: orthohealing@soba-cli.com

${ }^{2}$ Department of Orthopaedic Surgery, Sobajima Clinic, 2-2-6, Aramotokita, Higashiosaka, Osaka 577-0011, Japan

Full list of author information is available at the end of the article
}

(c) The Author(s). 2020 Open Access This article is licensed under a Creative Commons Attribution 4.0 International License, which permits use, sharing, adaptation, distribution and reproduction in any medium or format, as long as you give appropriate credit to the original author(s) and the source, provide a link to the Creative Commons licence, and indicate if changes were made. The images or other third party material in this article are included in the article's Creative Commons. licence, unless indicated otherwise in a credit line to the material. If material is not included in the article's Creative Commons licence and your intended use is not permitted by statutory regulation or exceeds the permitted use, you will need to obtain permission directly from the copyright holder. To view a copy of this licence, visit http://creativecommons.org/licenses/by/4.0/ The Creative Commons Public Domain Dedication waiver (http://creativecommons.org/publicdomain/zero/1.0/) applies to the data made available in this article, unless otherwise stated in a credit line to the data. 


\section{Background}

Osteoarthritis (OA), a chronic degenerative joint disorder characterized by articular cartilage destruction and osteophyte formation, is a prevalent cause of significant disability. Disability is particularly evident in the elderly, where $10-50 \%$ of the senior population is affected by $\mathrm{OA}$ and many are severely disabled $[1,2]$. Knee OA initiates changes in the cartilage, ligaments, tendons, and muscles of the knee joint [3], which lead to knee buckling, poor psychosocial outcomes, increased risk of falls, balance deficits, and limitation in certain physical activities [4-6]. The altered clinical status and functional disability lead to a decrease in the quality of life [7]. Recently, cell therapy with adipose tissue-derived mesenchymal stem cells (ADSCs) is attracting attention as a novel potential therapy for knee OA $[8,9]$. ADSCs share similar properties with bone marrow-derived mesenchymal stem cells (BMSCs), but they are easier to collect for clinical application, with higher isolation yields [9]. ADSCs, however, require culturing, and it takes a few weeks between isolation and application.

Adipose-derived stromal vascular fraction (SVF) cells contain regenerative cells, such as ADSCs, macrophages, blood cells, pericytes, fibroblasts, vessel-forming cells like endothelial and smooth muscle cells, and their progenitors [10-12]. SVF cells can be easily isolated in large amounts from autologous adipose tissue and used without culturing or differentiation $[13,14]$. The safety and efficacy of SVF cells have been examined in several clinical settings, such as cardiology [15], urology [16], plastic, and reconstructive surgery $[17,18]$. Studies have also reported the effectiveness of SVF cells in orthopedic clinical settings [19-21]. However, the detailed clinical evaluation of SVF cell treatment for knee OA while securing the sample size has not yet been reported in a large number of patients.

Based on this scientific background, we report a prospective case series of intra-articular injection of autologous SVF cells in knee OA. We investigated the short-term treatment effects in detail, and evaluated the safety, feasibility, and efficacy of intra-articular injections of autologous SVF cells.

\section{Methods}

\section{Study design and criteria for subject enrollment}

This clinical study was designed to evaluate the safety, feasibility, and efficacy of autologous SVF cells in patients with knee OA. The grade of knee OA was evaluated by the Kellgren-Lawrence (KL) classification, and all patients with grades I to IV OA participated in this study. The study protocol conformed to the Declaration of Helsinki and was approved by the appropriate ethics committees. All patients provided informed consent prior to participation.
The inclusion criteria were (a) patients diagnosed with knee OA at any age, (b) exhibiting substantial pain and loss of function, (c) ineffectiveness of conservative treatment including rehabilitation, medication, and intra-articular injection of hyaluronic acid or steroids, and (d) written informed consent. The exclusion criteria were (a) severe bony defect seen on preoperative radiographs, (b) previous knee injury requiring operation, (c) active or previous knee joint infection, and (d) a serious past history, such as systemic inflammatory diseases and vascular changes.

Patients were asked to perform daily home exercises by themselves according to a standardized rehabilitation protocol of the hospital after treatment, in addition to rehabilitation by a physical therapist through regular hospital visits.

\section{Treatment procedures (Fig. 1)}

The Celution ${ }^{\circledR}$ 800/CRS system (Cytori Therapeutics Inc., San Diego, CA) was used to extract SVF cells from the patient's abdominal or breech subcutaneous fat. This system consists of two parts: one for tissue washing and digestion, and the other for cell concentration. All subjects underwent a liposuction procedure to obtain $100-360 \mathrm{~mL}$ of adipose tissue under general anesthesia; the extracted tissue was then processed using the Celution ${ }^{\oplus} 800 /$ CRS System according to manufacturer instructions. Briefly, the tissue was washed to remove blood and debris. Celase ${ }^{\curvearrowleft}$ GMP, which was a mixture of highly purified collagenase and neutral protease enzymes, was then added and incubated at $\sim 37^{\circ} \mathrm{C}$ for $20 \mathrm{~min}$ with continuous mixing to digest the aspirated adipose tissue. After digestion, the SVF cells were concentrated using centrifugation and washed to remove the Celase ${ }^{\varpi}$ reagent. SVF cells were then extracted from the system and counted to prepare the specified dose in $5 \mathrm{~mL}$ of lactated Ringer's solution. The whole system can be operated aseptically using clinicalgrade solutions such as saline and lactated Ringer's, and single-use Celution $^{\mathrm{Tm}}$ consumable sets. The SVF cell count and viability were determined at each investigational site using the $\mathrm{NC}-100^{\mathrm{m}}$ NucleoCounter ${ }^{\ominus}$ Automated Cell Counting System (Chemometec, Allerod, Denmark). This system is an image cytometer based on fluorescence from the fluorescent dye, propidium iodide. When a sample is mixed with Reagent A100 and Reagent B, lysis of the viable cell membrane occurs, rendering all the cell nuclei susceptible to staining with propidium iodide facillitating in a total cell count. However, non-viable cells are permeable without treatment and are therefore stained directly with propidium iodide, resulting in a non-viable cell count. Thus, the cell viability of a sample is determined using the total cell count and the count of non-viable cells.

We administered an intra-articular injection of $2.5 \times$ $10^{7}$ SVF cells to each patient according to the number of 


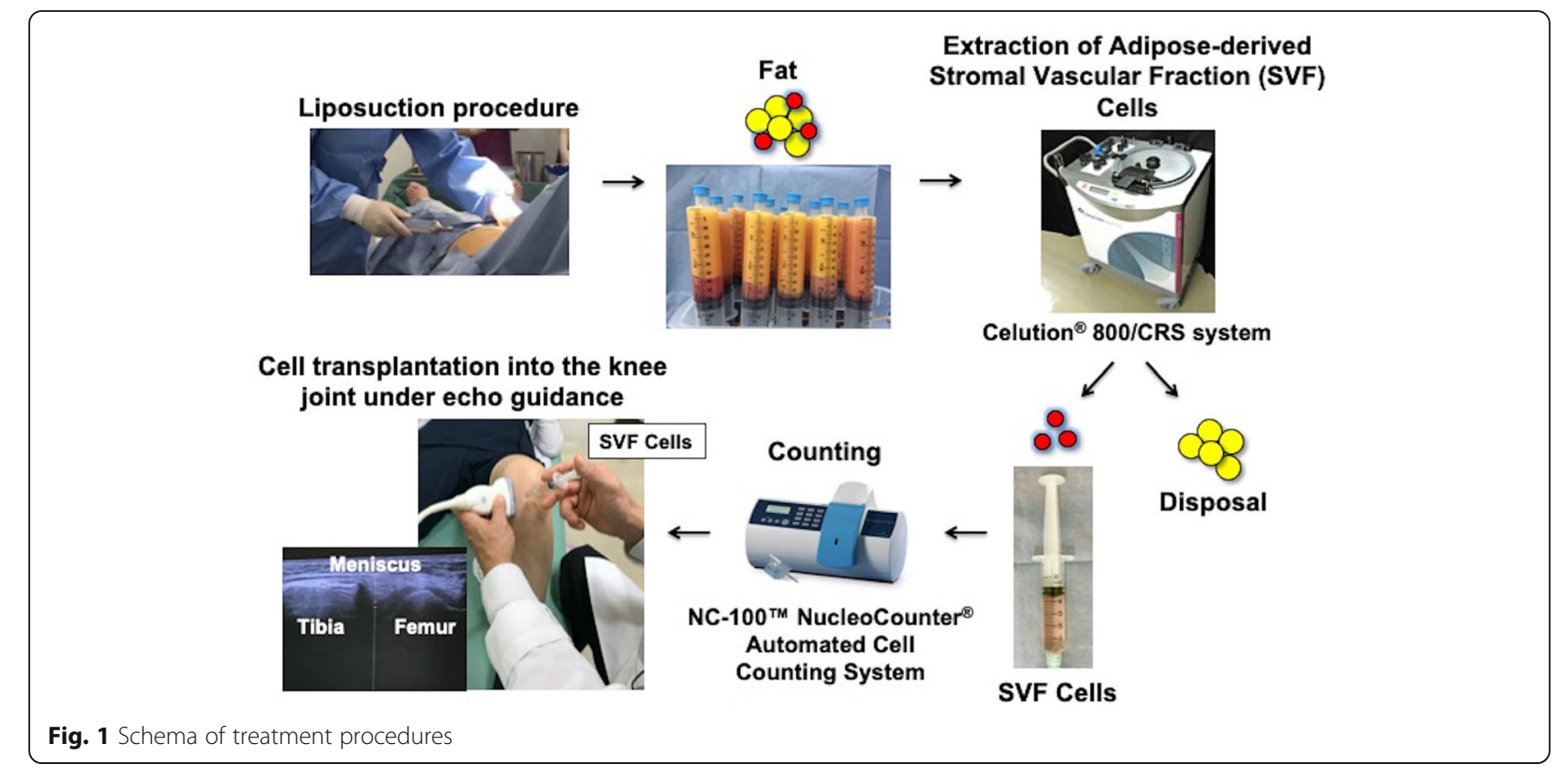

purified SVF cells and guidelines previously stated in a similar report [22]. Cell transplantation into the knee joint was performed without anesthetic and under echo guidance after aspiration if the joint fluid level was excessive.

\section{Endpoints}

The primary endpoint of this study was patient improvement based on clinical evaluations and scores. Clinical evaluations included knee range of motion (ROM) and muscle force of knee extension and flexion using a hand-held dynamometer. Clinical scores included Western Ontario and McMaster Universities Osteoarthritis Index (WOMAC), visual analog scale (VAS) for pain (0100), Japanese Knee Osteoarthritis Measure (JKOM), and Knee injury and Osteoarthritis Outcome Score (KOOS). For measurement of muscle force of knee extension and flexion, patients were tested in a prone position with their knee at 45 degrees flexion. The handheld dynamometer was placed at the center of their lower leg. The examiner asked subjects to bend their knee and hold for $3 \mathrm{~s}$ to measure hamstrings strength, and to straighten their knee and hold for $3 \mathrm{~s}$ to measure quadriceps strength. The examiner added resistance to maintain the knee at $45^{\circ}$ and measured the displayed value as muscle strength. These tests were performed three times and the average value was recorded.

As a secondary endpoint, imaging evaluations, which included the hip-knee-ankle (HKA) angle assessed via radiography, and $\mathrm{T} 2$ mapping value using a 1.5 - $\mathrm{T}$ magnetic resonance imaging (MRI) unit (Sigma Exite HDx; GE Healthcare, Waukesha, Wis) [23, 24] were also assessed. The method of calculating the T2 mapping value is as follows; we selected a central slice that passed through the center of the weight-bearing cartilage surrounded by the anterior and posterior margins of the meniscus on a sagittal slice of T1-weighted fastfield echo images. In addition to the central slice, we added two slices neighboring the central slice anteriorly and posteriorly (Fig. 2a). The region of interest (ROI) was then set at the weight-bearing full-thickness cartilage of the medial and lateral femoral condyle and medial and lateral tibial plateau on the central slice of the coronal image (Fig. 2b). The ROI was also set using the same method on both the anterior and posterior slice. Overall, the T2 mapping values of 12 ROIs were measured. According to this analysis, the lower the T2 mapping value, the lower the degree of articular cartilage degeneration.

Both clinical and imaging evaluations were performed preoperatively and at $1,3,6$ and 12 months postoperatively after intra-articular injection of SVF cells. Clinical evaluations were performed by an independent experienced physiotherapist. Image analyses were performed by an independent orthopedic surgeon with 15 years of experience in MRI analysis of knee OA features. For safety evaluations, incidence, severity, and outcome of all adverse events were recorded.

\section{Statistical analysis}

All values were expressed as mean \pm standard deviation. Results were analyzed using a statistical software package (Statview 5.0; Abacus Concepts, Inc., Berkeley, CA, USA). Clinical and imaging evaluations 


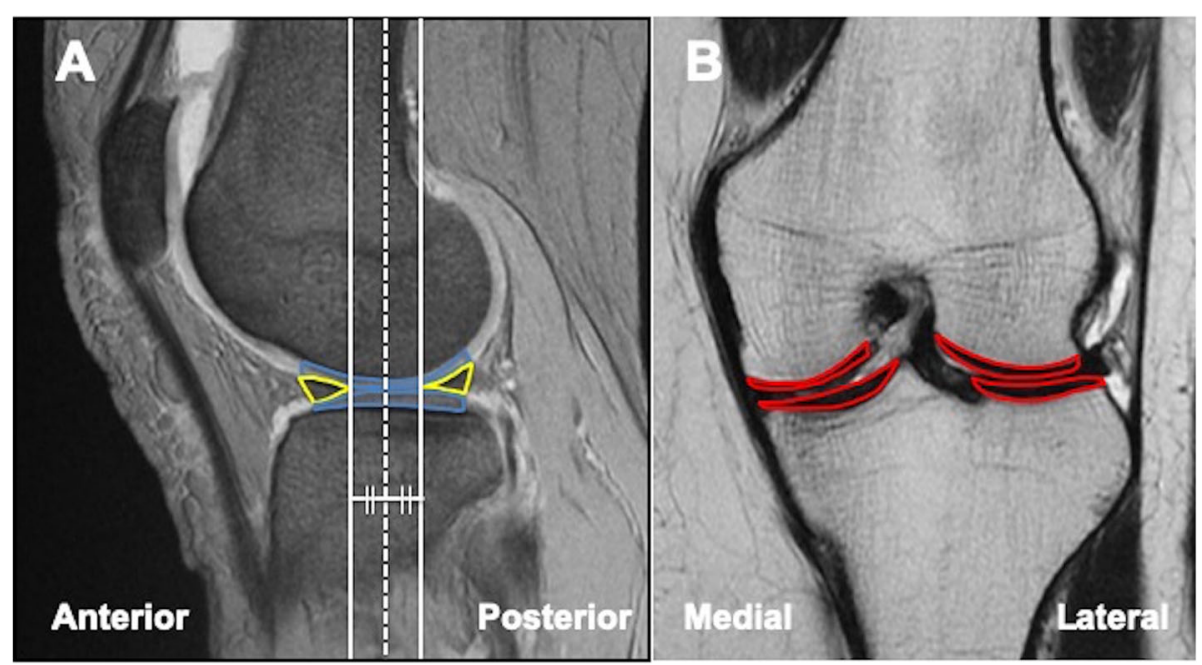

Fig. 2 Method of calculating the T2 mapping value. a In a sagittal slice of T1-weighted fast-field echo images, we select a central slice (white dotted line) that passed through the center of the weightbearing cartilage (blue line) surrounded by the anterior and posterior margins of the meniscus (yellow line). In addition to the central slice, we added two slices neighboring the central slice anteriorly and posteriorly. b The region of interest (ROI) was set at the weight-bearing full-thickness cartilage (red line) of the medial and lateral femoral condyle and medial and lateral tibial plateau on the central slice of the coronal image. The ROI was also set using the same method on both the anterior and posterior slice.

Overall, the T2 mapping values of 12 ROls were measured

were compared between the five time periods using repeated measures analysis of variance. Furthermore, we evaluated the clinical scores preoperatively and at 12 months postoperatively, and investigated the improvement rate of clinical scores from preoperatively to 12 months postoperatively among the KL classification by using repeated measures analysis of variance. $P<0.05$ was considered statistically significant. A statistical power analysis was performed prior to the study, which was expected to require a power of 0.8 , based on a prespecified significance level of $\alpha<0.05$ and assuming a medium effect size (effect size $=0.30$ ) using $G$ power 3 [25]. The estimated sample size was 45 patients.

\section{Results}

In total, 543 patients visited our clinic for SVF cell treatment between September 2017 and March 2018. Of them, 367 were excluded because they showed improvements in symptoms with conservative treatment including rehabilitation, medication, and intra-articular injection of hyaluronic acid or steroids. Eighty-seven patients refused to participate in this study. Twentynine were excluded based on exclusion criteria: (a) patients with severe bony defect observed on preoperative radiographs (7 patients), (b) patients with previous knee injury requiring operation (2 patients), (c) patients with active or previous knee joint infection (1 patients), and (d) patients with a serious past history (19 patients). As a result, 60 patients were enrolled and treated with intra-articular injection of SVF cells into the knee joint.
Three patients were lost to follow-up, leaving a total of 57 patients (57 knees) available for the study. The follow-up rate was 95.0\%. (Fig. 3). All patients were followed up for 12 months or longer. Mean age at treatment, follow-up period, and body mass index were $69.4 \pm 6.9$ years, $13.7 \pm 2.0$ months, and $25.1 \pm 3.1 \mathrm{~kg} / \mathrm{m} 2$, respectively. Patients were divided based on the KL classification: grade I, 0 patients; grade II, 11 patients; grade III, 36 patients; and grade IV, 10 patients. The mean preoperative HKA angle was $6.7 \pm 3.6^{\circ}$ (varus type knee OA, 53 knees; valgus knee OA, 4 knees), and the mean preoperative knee extension and flexion angles were $-6.0 \pm 5.9^{\circ}$ and $131.3 \pm 14.2^{\circ}$, respectively (Table 1).

The mean volume of liposuction and number of purified SVF cells were $334.3 \pm 44.0 \mathrm{~mL}$ and $7.6 \times 10^{7} \pm 2.5 \times 10^{7}$, respectively. Mean SVF cell viability was $90.6 \% \pm 2.7 \%$.

\section{Clinical evaluation}

The mean ROM improved from a baseline of $-6.0^{\circ}-131.3^{\circ}$ to $-4.8^{\circ}-133.9^{\circ}$ at 1 month, $-4.3^{\circ}-134.3^{\circ}$ at 3 months, $3.7^{\circ}-134.5^{\circ}$ at 6 months, and $-3.5^{\circ}-132.6^{\circ}$ at 12 months postoperatively. The improvement in the mean extension angle from baseline to 6 and 12 months was statistically significant. Muscle force of knee extension and flexion improved from a baseline of $202.5 \mathrm{Nm}$ and $99.5 \mathrm{Nm}$, respectively, to $198.9 \mathrm{Nm}$ and $108.2 \mathrm{Nm}$ at 1 month, $219.0 \mathrm{Nm}$ and $116.6 \mathrm{Nm}$ at 3 months, $235.4 \mathrm{Nm}$ and $124.2 \mathrm{Nm}$ at 6 months, and $261.9 \mathrm{Nm}$ and $126.8 \mathrm{Nm}$ at 12 months postoperatively, respectively. The mean muscle force of knee 


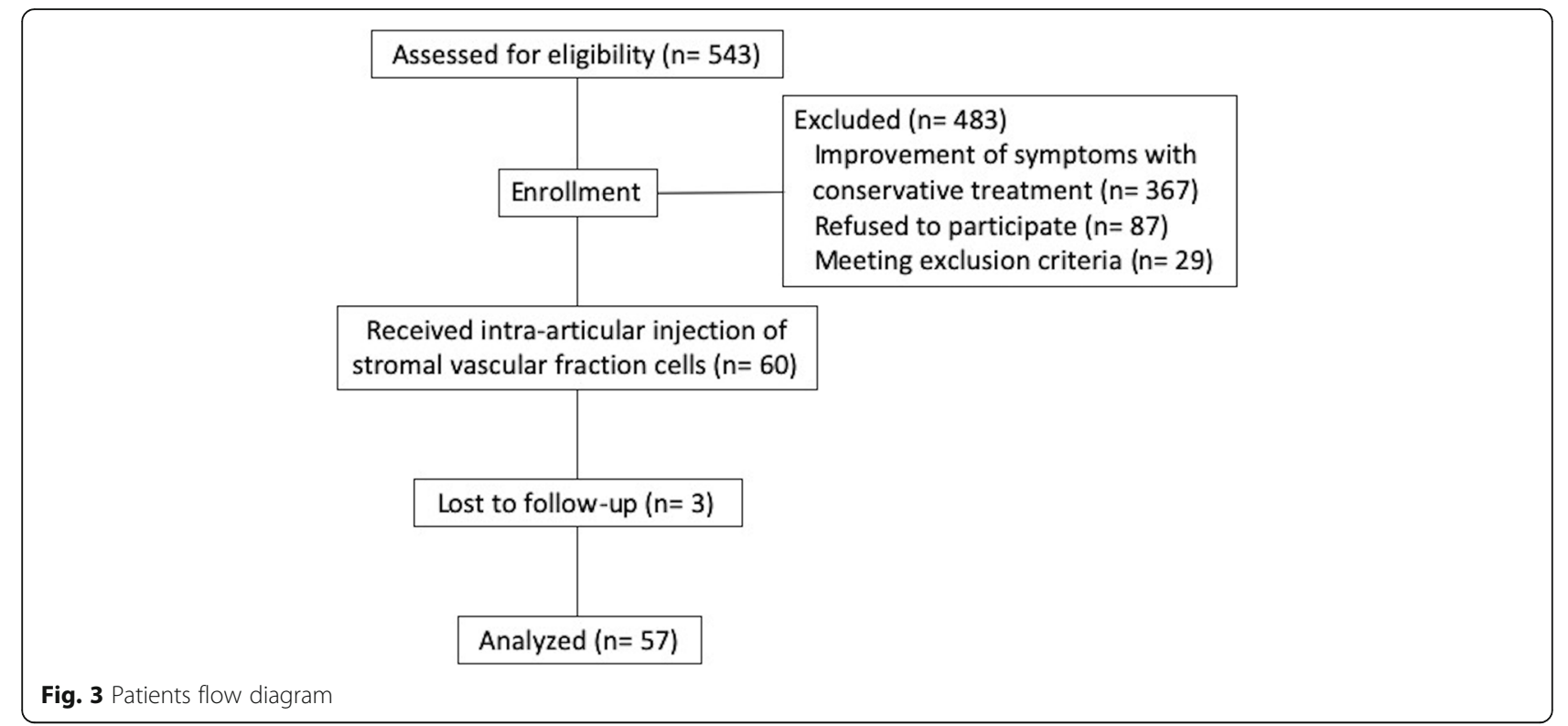

extension and flexion was significantly better at 12 months postoperatively than preoperatively.

The improvement in the mean total WOMAC scores from baseline to 12 months postoperatively was from 33.4 to 22.6 points, which showed a statistically and clinically significant difference (Table 2). The improvement in VAS scores from baseline to 12 months postoperatively was from 46.5 to 32.8 points, which showed a statistically and clinically significant difference (Table 2). An improvement was also evident in the mean total JKOM scores from baseline to 12 months postoperatively (from 34.9 to 26.8 points), which showed a statistically significant difference (Table 2). Improvements in the KOOS score were also evident, including an average score of 5 subscales and all subscale scores 12 months

Table 1 Patient characteristics

\begin{tabular}{ll}
\hline Characteristics & Baseline Data \\
\hline Sex (M/F); $\mathrm{n}(\%)$ & $41 / 16(72 \% / 28 \%)$ \\
Age (mean \pm standard deviation); yrs & $69.4 \pm 6.9$ \\
Body mass index; kg/m² & $25.1 \pm 3.1$ \\
Duration of follow-up; months & $13.7 \pm 2.0$ \\
Hip-knee-ankle angle at baseline; degree & $6.7 \pm 3.6$ \\
Knee extension angle; degree & $-6.0 \pm 5.9$ \\
Knee flexion angle; degree & $131.3 \pm 14.2$ \\
Kellgren- Lawrence classificationn (\%) & \\
I & $0(0 \%)$ \\
II & $11(19 \%)$ \\
III & $36(63 \%)$ \\
IV & $10(18 \%)$ \\
\hline
\end{tabular}

postoperatively (Table 2, Additional file 1). The improvements from baseline in the mean scores of pain, symptoms, activities of daily living, sports, and quality of life subscales were from 53.1 to 66.3 points, 57.8 to 67.0 points, 70.0 to 77.5 points, 27.6 to 37.5 points, and 33.6 to 44.6 points with statistical significance, respectively. The improvements in the mean scores of pain, symptoms, sports, and quality of life subscales also showed clinically significant differences (Additional file 1).

According to the KL classification, there were no grade I patients in this study. There was no significant difference in preoperative clinical scores of WOMAC, VAS, $\mathrm{JKOM}$, and KOOS among the KL classifications. Clinical scores of WOMAC, JKOM and KOOS at 12 months postoperatively were significantly better for grade II than for grade III. Furthermore, clinical scores of WOMAC, VAS, and JKOM at 12 months postoperatively were also significantly better for grade II than for grade IV. The improvement rate of WOMAC from baseline to 12 months was significantly better for grade II than for grade III. There was no significant difference in improvement rates of VAS, JKOM, and KOOS among the KL classifications (Table 3).

\section{Imaging evaluation}

The mean HKA angles changed from a baseline of $6.7^{\circ}$ to $7.1^{\circ}$ at 1 month, $6.7^{\circ}$ at 3 months, $6.6^{\circ}$ at 6 months, and $6.8^{\circ}$ at 12 months postoperatively. However, this change was not statistically significant at any time. In contrast, the mean T2 mapping values of the lateral femur and tibia in the anterior areas at 12 months postoperatively were significantly lower than those preoperatively. The mean T2 mapping value of the medial tibia in the central area at 
Table 2 Clinical evaluation results

\begin{tabular}{|c|c|c|c|c|c|}
\hline \multicolumn{6}{|c|}{ Range of motion of the knee } \\
\hline Extension & Mean value \pm S.D. $\left(^{\circ}\right)$ & $P$ value & Flexion & Mean value \pm S.D. $\left({ }^{\circ}\right)$ & $P$ value \\
\hline Preoperative & $-6.0 \pm 5.9$ & & Preoperative & $131.3 \pm 14.2$ & \\
\hline 1 month & $-4.8 \pm 4.8$ & 0.23 & 1 month & $133.9 \pm 12.5$ & 0.37 \\
\hline 3 months & $-4.3 \pm 4.5$ & 0.10 & 3 months & $134.3 \pm 11.9$ & 0.29 \\
\hline 6 months & $-3.7 \pm 4.4$ & $0.02^{\mathrm{a}}$ & 6 months & $134.5 \pm 12.4$ & 0.26 \\
\hline 12 months & $-3.5 \pm 4.1$ & $0.02^{\mathrm{a}}$ & 12 months & $132.6 \pm 15.2$ & 0.67 \\
\hline \multicolumn{6}{|l|}{ Muscle force } \\
\hline Extension (Quadriceps) & Mean value \pm S.D. $(\mathrm{Nm})$ & $P$ value & Flexion (Hamstrings) & Mean value \pm S.D. $(\mathrm{Nm})$ & $P$ value \\
\hline Preoperative & $202.5 \pm 85.9$ & & Preoperative & $99.5 \pm 39.7$ & \\
\hline 1 month & $198.9 \pm 91.1$ & 0.86 & 1 month & $108.2 \pm 41.3$ & 0.36 \\
\hline 3 months & $219.0 \pm 103.8$ & 0.43 & 3 months & $116.6 \pm 59.8$ & 0.07 \\
\hline 6 months & $235.4 \pm 104.5$ & 0.11 & 6 months & $124.2 \pm 41.7$ & $<0.01^{\mathrm{a}}$ \\
\hline 12 months & $261.9 \pm 106.7$ & $<0.01^{a}$ & 12 months & $126.8 \pm 38.7$ & $<0.01^{\mathrm{a}}$ \\
\hline \multicolumn{3}{|c|}{ Western Ontario and McMaster Universities Osteoarthritis Index } & Visual analog scale & & \\
\hline Total Score & Mean value \pm S.D. & $P$ value & & Mean value \pm S.D. & $P$ value \\
\hline Preoperative & $33.4 \pm 18.2$ & & Preoperative & $46.5 \pm 23.5$ & \\
\hline 1 month & $26.3 \pm 14.6$ & $0.046^{\mathrm{a}}$ & 1 month & $30.1 \pm 18.8$ & $<0.01^{\mathrm{a}}$ \\
\hline 3 months & $22.8 \pm 15.7$ & $<0.01^{\mathrm{a}}$ & 3 months & $27.3 \pm 17.6$ & $<0.01^{\mathrm{a}}$ \\
\hline 6 months & $22.6 \pm 16.4$ & $<0.01^{\mathrm{a}}$ & 6 months & $27.4 \pm 18.8$ & $<0.01^{\mathrm{a}}$ \\
\hline 12 months & $22.6 \pm 17.5$ & $<0.01^{\mathrm{a}}$ & 12 months & $32.8 \pm 24.7$ & $<0.01^{\mathrm{a}}$ \\
\hline \multicolumn{3}{|c|}{ Japanese Knee Osteoarthritis Measure } & \multicolumn{3}{|c|}{ Knee injury and Osteoarthritis Outcome Score } \\
\hline Total Score & Mean value \pm S.D. & $P$ value & Average Score of 5 subscales & Mean value \pm S.D. & $P$ value \\
\hline Preoperative & $34.9 \pm 18.2$ & & Preoperative & $48.7 \pm 15.8$ & \\
\hline 1 month & $30.5 \pm 17.1$ & 0.26 & 1 month & $55.2 \pm 17.6$ & $0.04^{\mathrm{a}}$ \\
\hline 3 months & $25.8 \pm 17.6$ & $0.02^{\mathrm{a}}$ & 3 months & $58.6 \pm 15.4$ & $<0.01^{\mathrm{a}}$ \\
\hline 6 months & $24.5 \pm 17.8$ & $<0.01^{\mathrm{a}}$ & 6 months & $59.2 \pm 15.8$ & $<0.01^{\mathrm{a}}$ \\
\hline 12 months & $26.8 \pm 19.7$ & $0.04^{\mathrm{a}}$ & 12 months & $58.6 \pm 16.8$ & $<0.01^{\mathrm{a}}$ \\
\hline
\end{tabular}

a Statistically significant, Standard deviation (S.D.)

6 and 12 months postoperatively was also significantly better than that preoperatively. Furthermore, the mean T2 mapping value of the lateral femur in the posterior area at 12 months postoperatively was significantly better than that preoperatively (Table 4, Fig. 4).

\section{Safety evaluation}

Neither deaths nor life-threatening adverse events were observed during the 12-month follow-up after cell therapy. Furthermore, there was no mild to moderate adverse event such as swelling, local heat of the knee, or infection during follow-up.

\section{Discussion}

Clinical evaluation showed widespread improvement in multiple parameters early after intra-articular SVF cell injection into the knees of OA patients. Most imaging evaluations, especially T2 mapping values, showed similar trends; however, most of these imaging evaluations did not achieve statistical significance. This may be because of the well-known placebo effect of injectable therapies in patient-reported outcomes, or to the limited follow-up duration, as most studies only evaluate the knee via MRI over the course of 1-2 years.

There have been a few reports on good clinical results of ADSC cell therapy for knee OA $[8,9]$. ADSCs and BMSCs share similar properties, but require culturing after isolation. In contrast, SVF cells are not cultured and can be prepared from and reinjected back into the patient within the same procedure. Equivalent to BMSCs, SVF cells contain cells with multilineage potential and can be easily isolated in large amounts from autologous adipose tissues and 
Table 3 Improvement rate from baseline to 12-month postoperatively in Western Ontario and McMaster Universities Osteoarthritis Index (WOMAC), visual analog scale (VAS) for pain, Japanese Knee Osteoarthritis Measure (JKOM), and Knee injury and Osteoarthritis Outcome Score (KOOS) scores among Kellgren-Lawrence classifications

\begin{tabular}{|c|c|c|c|c|c|c|c|}
\hline & \multirow{2}{*}{$\begin{array}{l}\text { Clinical } \\
\text { score }\end{array}$} & \multicolumn{3}{|c|}{ Kellgren-Lawrence classification } & \multicolumn{3}{|l|}{$P$ value } \\
\hline & & Grade II (11 patients) & Grade III (36 patients) & Grade IV (10 patients) & Gradell vs III & Gradell vs IV & Gradelll vs IV \\
\hline Preoperative & WOMAC & $27.7 \pm 15.1$ & $35.1 \pm 17.5$ & $37.6 \pm 21.5$ & 0.27 & 0.21 & 0.70 \\
\hline \multirow[t]{3}{*}{ score } & VAS & $35.5 \pm 18.6$ & $52.1 \pm 22.7$ & $55.4 \pm 30.8$ & 0.07 & 0.06 & 0.70 \\
\hline & $\mathrm{JKOM}$ & $27.4 \pm 15.3$ & $37.4 \pm 18.5$ & $37.1 \pm 20.8$ & 0.15 & 0.24 & 0.97 \\
\hline & KOOS & $52.9 \pm 12.0$ & $48.6 \pm 17.5$ & $45.4 \pm 14.6$ & 0.46 & 0.28 & 0.56 \\
\hline 12 months & WOMAC & $11.2 \pm 9.4$ & $26.0 \pm 16.6$ & $25.7 \pm 17.1$ & $0.01^{\mathrm{a}}$ & $0.04^{\mathrm{a}}$ & 0.96 \\
\hline \multirow[t]{3}{*}{ score } & VAS & $20.7 \pm 20.2$ & $37.4 \pm 24.6$ & $42.4 \pm 25.8$ & 0.07 & $0.045^{\mathrm{a}}$ & 0.56 \\
\hline & JKOM & $14.4 \pm 9.6$ & $31.6 \pm 20.1$ & $32.2 \pm 18.5$ & $0.01^{a}$ & $0.03^{\mathrm{a}}$ & 0.92 \\
\hline & KOOS & $68.5 \pm 14.3$ & $56.3 \pm 17.9$ & $56.1 \pm 14.0$ & $0.048^{a}$ & 0.08 & 0.97 \\
\hline Improvement & WOMAC & $58.5 \pm 26.5$ & $22.8 \pm 46.8$ & $28.8 \pm 22.1$ & $0.02^{a}$ & 0.09 & 0.67 \\
\hline \multirow[t]{3}{*}{ rate } & VAS & $14.8 \pm 20.0$ & $14.7 \pm 20.9$ & $13.0 \pm 18.3$ & 0.99 & 0.84 & 0.81 \\
\hline & JKOM & $34.4 \pm 49.9$ & $7.4 \pm 56.6$ & $5.7 \pm 27.8$ & 0.15 & 0.20 & 0.92 \\
\hline & KOOS & $19.1 \pm 24.2$ & $11.2 \pm 27.9$ & $17.7 \pm 21.2$ & 0.41 & 0.90 & 0.47 \\
\hline
\end{tabular}

Mean value \pm Standard deviation (S.D.) ${ }^{\text {a }}$ Statistically significant

used without culturing [13, 14]. SVF cells have been used for various clinical purposes [15-18], and studies on autologous SVF cells for the treatment of knee OA have been reported [19-21]. Fodor et al. reported that autologous adipose derived SVF cells were safe and presented a new potential therapy for pain reduction in knee OA, and Hong et al. reported that SVF cell treatment could be more effective than treatment with hyaluronic acid, although their sample size was small [19]. Although Michialek et al. reported that a large clinical trial of intra-articular SVF cell injections were a safe and clinically effective strategy leading to improved quality of life, detailed clinical evaluations were not performed [20]. In this clinical study, we performed the detailed clinical evaluation while securing the sample size.

In the current investigation, the mean total WOMAC, JKOM, VAS, and average 5-subscale KOOS scores 3, 6, and 12 months postoperatively were significantly better than preoperative scores. This was particularly evident in WOMAC and KOOS, for which all subscales at 3, 6, and 12 months postoperatively were significantly better than those preoperatively. The WOMAC instrument is a 24-item patient-reported instrument developed to assess pain, stiffness, and physical functioning in patients with hip or knee OA [26]. The physical function section of the WOMAC provides patients with a list of daily activities and requires them to state how difficult the activities were in the last $48 \mathrm{~h}$ because of their arthritis. KOOS is a disease-specific, patient-reported outcome measure assessing perceived pain, other symptoms, $\mathrm{ADL}$, sports and recreation functions, and knee- related quality of life. It is freely accessible and intended for use in the short and long term for research and clinical purposes [27]. WOMAC physical function and KOOS ADL items are identical. Sports and recreation functions and knee-related quality of life subscales were not referred in the WOMAC. Intra-articular SVF cell injection into knees with OA was thought to greatly improve sporting activities that required a higher level of activity than $\mathrm{ADL}$, as well as knee-related quality of life.

T2 mapping is a quantitative cartilage imaging technique that facilitates detection of changes in water and collagen content. Thus, T2 mapping values reflect the degree of articular cartilage degeneration [23, 24]. Although obvious improvement in coronal alignment was not observed in this study, the mean T2 mapping values of the lateral tibia in the anterior area and lateral femur in the anterior and posterior areas at 12 months postoperatively were significantly lower than those seen preoperatively. This indicated that the extent of articular cartilage degeneration was improved even if no obvious structural change was observed via MRI. Furthermore, the T2 mapping value of the lateral femur and tibia confirmed this improvement because mechanical stress was not applied on the lateral side, and almost all patients included in this study (55 of 59 patients; 93.2\%) had varus knee OA. The mean T2 mapping value of the medial tibia in the central area at 6 and 12 months postoperatively was also significantly lower than those seen preoperatively. This result was thought to be due to the fact that the region of interest was set in the remaining cartilage 
Table 4 Imaging evaluation results

\begin{tabular}{|c|c|c|c|c|c|c|c|c|}
\hline Hip-knee-ankle angle & Mean value \pm S.D. & $P$ value & & & & & & \\
\hline Preoperative & $6.7 \pm 3.6$ & & & & & & & \\
\hline 1 month & $7.1 \pm 3.5$ & 0.59 & & & & & & \\
\hline 3 months & $6.7 \pm 3.9$ & 0.94 & & & & & & \\
\hline 6 months & $6.6 \pm 3.6$ & 0.92 & & & & & & \\
\hline 12 months & $6.8 \pm 3.7$ & 0.90 & & & & & & \\
\hline \multicolumn{3}{|c|}{ Anterior T2 mapping value } & \multicolumn{3}{|c|}{ Central T2 mapping value } & \multicolumn{3}{|c|}{ Posterior T2 mapping value } \\
\hline Medial femur & Mean value \pm S.D. & $P$ value & Medial femur & Mean value \pm S.D. & $P$ value & Medial femur & Mean value \pm S.D. & $P$ value \\
\hline Preoperative & $51.5 \pm 5.0$ & & Preoperative & $51.4 \pm 4.6$ & & Preoperative & $52.9 \pm 5.2$ & \\
\hline 1 month & $50.0 \pm 2.4$ & 0.20 & 1 month & $50.7 \pm 4.1$ & 0.60 & 1 month & $51.2 \pm 4.8$ & 0.25 \\
\hline 3 months & $50.7 \pm 4.1$ & 0.52 & 3 months & $50.7 \pm 4.2$ & 0.62 & 3 months & $51.6 \pm 4.8$ & 0.37 \\
\hline 6 months & $50.1 \pm 3.0$ & 0.22 & 6 months & $49.8 \pm 4.7$ & 0.28 & 6 months & $52.0 \pm 4.4$ & 0.56 \\
\hline 12 months & $50.3 \pm 4.6$ & 0.054 & 12 months & $50.4 \pm 5.4$ & 0.18 & 12 months & $51.8 \pm 4.8$ & 0.22 \\
\hline Medial tibia & & & \multicolumn{3}{|l|}{ Medial tibia } & \multicolumn{3}{|l|}{ Medial tibia } \\
\hline Preoperative & $42.6 \pm 7.2$ & & Preoperative & $42.0 \pm 6.0$ & & Preoperative & $42.1 \pm 6.7$ & \\
\hline 1 month & $40.6 \pm 6.0$ & 0.26 & 1 month & $40.7 \pm 5.0$ & 0.39 & 1 month & $40.7 \pm 5.4$ & 0.39 \\
\hline 3 months & $40.8 \pm 5.5$ & 0.29 & 3 months & $40.4 \pm 5.8$ & 0.28 & 3 months & $41.0 \pm 5.8$ & 0.52 \\
\hline 6 months & $39.1 \pm 3.3$ & 0.053 & 6 months & $38.4 \pm 2.7$ & $0.02^{\mathrm{a}}$ & 6 months & $39.3 \pm 3.2$ & 0.11 \\
\hline 12 months & $39.7 \pm 3.9$ & 0.12 & 12 months & $37.9 \pm 2.8$ & $0.01^{\mathrm{a}}$ & 12 months & $38.8 \pm 3.8$ & 0.08 \\
\hline Lateral femur & & & \multicolumn{3}{|l|}{ Lateral femur } & \multicolumn{3}{|l|}{ Lateral femur } \\
\hline Preoperative & $43.4 \pm 3.3$ & & Preoperative & $48.1 \pm 4.7$ & & Preoperative & $47.0 \pm 4.7$ & \\
\hline 1 month & $42.3 \pm 3.7$ & 0.24 & 1 month & $47.9 \pm 4.8$ & 0.85 & 1 month & $46.1 \pm 4.6$ & 0.49 \\
\hline 3 months & $42.4 \pm 3.2$ & 0.29 & 3 months & $46.7 \pm 3.8$ & 0.27 & 3 months & $45.1 \pm 3.3$ & 0.13 \\
\hline 6 months & $41.8 \pm 3.4$ & 0.10 & 6 months & $47.3 \pm 4.0$ & 0.56 & 6 months & $44.6 \pm 4.4$ & 0.07 \\
\hline 12 months & $41.3 \pm 1.7$ & $0.047^{a}$ & 12 months & $46.4 \pm 2.4$ & 0.22 & 12 months & $43.4 \pm 3.1$ & $0.01^{\mathrm{a}}$ \\
\hline Lateral tibia & & & \multicolumn{3}{|l|}{ Lateral tibia } & \multicolumn{3}{|l|}{ Lateral tibia } \\
\hline Preoperative & $39.6 \pm 2.1$ & & Preoperative & $37.2 \pm 2.5$ & & Preoperative & $37.4 \pm 2.5$ & \\
\hline 1 month & $38.3 \pm 2.2$ & 0.06 & 1 month & $36.6 \pm 3.5$ & 0.43 & 1 month & $37.3 \pm 2.9$ & 0.85 \\
\hline 3 months & $39.3 \pm 2.8$ & 0.72 & 3 months & $36.9 \pm 2.3$ & 0.67 & 3 months & $38.0 \pm 2.9$ & 0.45 \\
\hline 6 months & $37.7 \pm 2.3$ & $0.01^{\mathrm{a}}$ & 6 months & $35.7 \pm 2.4$ & 0.07 & 6 months & $37.1 \pm 2.6$ & 0.67 \\
\hline 12 months & $37.6 \pm 1.5$ & $0.04^{\mathrm{a}}$ & 12 months & $36.7 \pm 2.2$ & 0.60 & 12 months & $37.1 \pm 2.6$ & 0.74 \\
\hline
\end{tabular}

a Statistically significant, Standard deviation (S.D)

at the non-weighted part, because cartilage defect was found in the weighted part of the medial tibia in almost all the cases in this study.

We evaluated the clinical scores preoperatively and 12 months postoperatively and investigated the improvement rate of clinical scores from preoperatively to 12 months postoperatively among the KL classification. The improvement rate of WOMAC scores from baseline to 12 months was significantly better for grade II than for grade III and tended to be better for grade II than for grade IV. Furthermore, the improvement rate of JKOM scores tended to be better for grade II than for grade III and IV. These results indicated that it was desirable to perform the treatment of SVF cells before the degree of degeneration of knee OA had progressed excessively.

This study has some limitations. First, this study had no control group. We plan to investigate the association between SVF cells and other intra-articular interventions in the future. Second, clinical and imaging evaluations were only performed preoperatively, and at $1,3,6$, and 12 months after intra-articular SVF cell injection into the knee. Long-term investigation of clinical and structural changes is now ongoing. Third, we did not evaluate the relationship between dosage of intra-articular SVF cell injection and clinical/structural results. Finally, this study applied a single treatment of SVF cells. Optimal treatment may require multiple injections. 

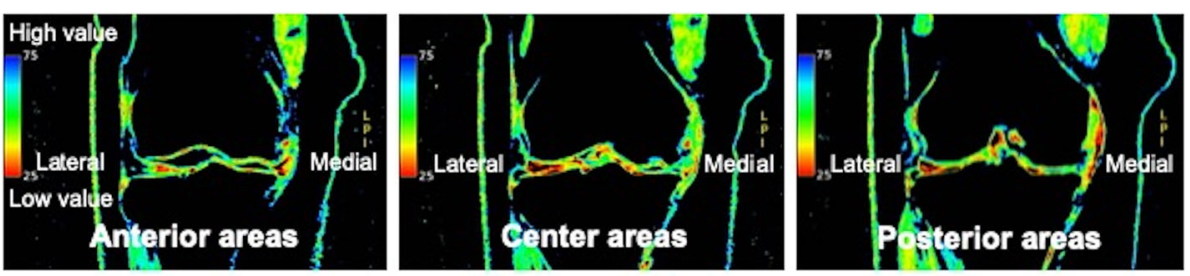

\section{Preoperative}
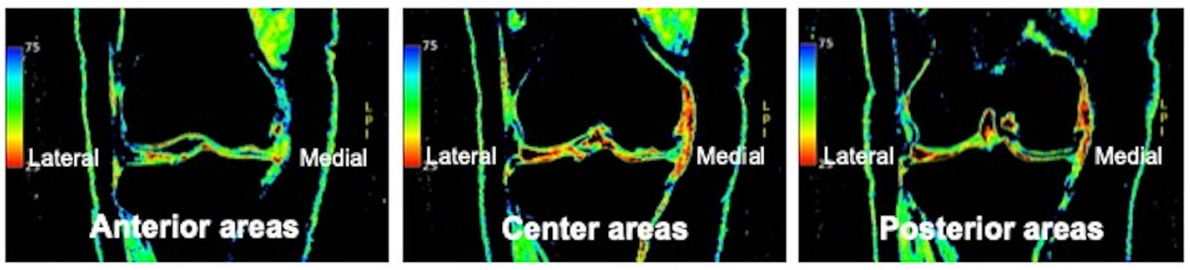

\section{Postoperative}

Fig. 4 An example in which the mean T2 mapping values were significantly lower than those preoperatively

\section{Conclusions}

We performed detailed clinical evaluations of intraarticular autologous SVF cell injection for knee OA while securing the sample size, and obtained good short-term clinical results. All procedures were performed safely. The short-term clinical evaluation of intra-articular SVF cell injection on knee OA was very promising. We suggest intra-articular SVF cell injection into the knee joint as an innovative approach to treat patients with knee OA.

\section{Supplementary information}

Supplementary information accompanies this paper at https://doi.org/10. 1186/s12891-020-03231-3.

Additional file 1. Each subscale score of Western Ontario and McMaster Universities Osteoarthritis Index, visual analog scale, Japanese Knee Osteoarthritis Measure, and Knee injury and Osteoarthritis Score.

\section{Abbreviations}

OA: Osteoarthritis; ADSCs: Adipose tissue-derived mesenchymal stem cells; BMSCs: Bone marrow-derived mesenchymal stem cells; SVF: Stromal vascular fraction; KL: Kellgren-Lawrence; ROM: range of motion; WOMAC: Western Ontario and McMaster Universities Osteoarthritis Index; VAS: Visual analog scale; JKOM: Japanese Knee Osteoarthritis Measure; KOOS: Knee injury and Osteoarthritis Outcome Score; HKA: Hip-knee-ankle; MRI: Magnetic resonance imaging; ADL: Activities of daily living

\section{Acknowledgements}

We wish to thank Hitoshi Yamauchi and Yusuke Harada for collecting data.

\section{Authors' contributions}

All authors have made substantial contributions to (1) the conception and design of the study, or acquisition of data, or analysis and interpretation of data; (2) drafting the article or revising it critically for important intellectual content; and (3) final approval of the version to be submitted. The specific contributions of the authors are as follows: (1) Conception and design of the study: [TM]1, SS, RK. (2) Analysis and interpretation of the data: all authors, Drafting of the article: [TM]2, HI, MT. (3) Final approval: all authors.

\section{Funding}

Not applicable.
Availability of data and materials

The datasets used and/or analyzed during the current study are available from the corresponding author on reasonable request.

Ethics approval and consent to participate

This study was approved by the Ethics Committee of Sobajima Clinic. Written, informed consent was obtained from each participant.

\section{Consent for publication}

Not applicable.

\section{Competing interests}

The authors declare that they have no competing interests.

\section{Author details}

'Department of Orthopaedic Surgery, Kobe University Graduate School of Medicine, Kobe, Japan. '2Department of Orthopaedic Surgery, Sobajima Clinic, 2-2-6, Aramotokita, Higashiosaka, Osaka 577-0011, Japan.

Received: 10 January 2020 Accepted: 24 March 2020 Published online: 06 April 2020

\section{References}

1. Doherty M. Risk factors for progression of knee osteoarthritis. Lancet. 2001; 358:775-6.

2. Haywood L, McWilliams DF, Pearson Cl, Gill SE, Ganesan A, Wilson D, et al. Inflammation and angiogenesis in osteoarthritis. Arthritis Rheum. 2003:48:2173-7.

3. Mundermann A, Nigg BM, Humble RN, Stefanyshyn DJ. Orthotic comfort is related to kinematics, kinetics, and EMG in recreational runners. Med Sci Sports Exerc. 2003;35:1710-9.

4. Hallemans A, Ortibus E, Truijen S, Meire F. Development of independent locomotion in children with a severe visual impairment. Res Dev Disabil. 2011;32:2069-74.

5. Messier SP, Loeser RF, Hoover JL, Semble EL, Wise CM. Osteoarthritis of the knee: effects on gait, strength, and flexibility. Arch Phys Med Rehabil. 1992;73:29-36.

6. Nguyen US, Felson DT, Niu J, White DK, Segal NA, Lewis CE, et al. The impact of knee instability with and without buckling on balance confidence, fear of falling and physical function: the multicenter osteoarthritis study. Osteoarthr Cartil. 2014;22:527-34.

7. Alkan BM, Fidan F, Tosun A, Ardıçoğlu O. Quality of life and self-reported disability in patients with knee osteoarthritis. Mod Rheumatol. 2014;24:166-71.

8. Jo CH, Lee YG, Shin WH, Kim H, Chai JW, Jeong EC, et al. Intra-articular injection of mesenchymal stem cells for the treatment of osteoarthritis of the knee: a proof-of-concept clinical trial. Stem Cells. 2014;32:1254-66. 
9. Pers YM, Rackwitz L, Ferreira R, Pullig O, Delfour C, Barry F, et al. Adipose Mesenchymal stromal cell-based therapy for severe osteoarthritis of the knee: a phase I dose-escalation trial. Stem Cells Transl Med. 2016;5:847-56.

10. Bourin P, Bunnell BA, Casteilla L, Dominici M, Katz AJ, March KL, et al. Stromal cells from the adipose tissue-derived stromal vascular fraction and culture expanded adipose tissue-derived stromal/stem cells: a joint statement of the International Federation for Adipose Therapeutics and Science (IFATS) and the International Society for Cellular Therapy (ISCT). Cytotherapy. 2013;15:641-8.

11. Han J, Koh YJ, Moon HR, Ryoo HG, Cho CH, Kim I, et al. Adipose tissue is an extramedullary reservoir for functional hematopoietic stem and progenitor cells. Blood. 2010;115:957-64.

12. McIntosh K, Zvonic S, Garrett S, Mitchell JB, Floyd ZE, Hammill L, et al. The immunogenicity of human adipose-derived cells: temporal changes in vitro. Stem Cells. 2006;24:1246-53.

13. De Ugarte DA, Morizono K, Elbarbary A, Alfonso Z, Zuk PA, Zhu M, et al. Comparison of multi-lineage cells from human adipose tissue and bone marrow. Cells Tissues Organs. 2003;174:101-9.

14. Feng Z, Ting J, Alfonso Z, Strem BM, Fraser JK, Rutenberg J, et al. Fresh and cryopreserved, uncultured adipose tissue-derived stem and regenerative cells ameliorate ischemia-reperfusion-induced acute kidney injury. Nephrol Dial Transplant. 2010;25:3874-84.

15. Kastrup J, Schou M, Gustafsson I, Nielsen OW, Møgelvang R, Kofoed KF, et al. Rationale and Design of the First Double-Blind, Placebo-Controlled Trial with Allogeneic Adipose Tissue-Derived Stromal Cell Therapy in Patients with Ischemic Heart Failure: A Phase II Danish Multicentre Study. Stem Cells Int. 2017:2017:8506370.

16. Alatab S, Shekarchian S, Najafi I, Moghadasali R, Ahmadbeigi N, Pourmand MR, et al. Systemic infusion of autologous adipose tissue-derived Mesenchymal stem cells in peritoneal Dialysis patients: feasibility and safety. Cell J. 2019;20:483-95.

17. Lasso JM, Poletti D, Scola B, Gómez-Vilda P, García-Martín Al, FernándezSantos ME. Injection Laryngoplasty using autologous fat enriched with adipose-derived regenerative stem cells: a safe therapeutic option for the functional reconstruction of the glottal gap after unilateral vocal fold paralysis. Stem Cells Int. 2018;2018:8917913.

18. Mazur S, Zolocinska A, Siennicka K, Janik-Kosacka K, Chrapusta A, Pojda Z. Safety of adipose-derived cell (stromal vascular fraction - SVF) augmentation for surgical breast reconstruction in cancer patients. Adv Clin Exp Med. 2018;27:1085-90.

19. Fodor PB, Paulseth SG. Adipose derived stromal cell (ADSC) injections for pain Management of Osteoarthritis in the human knee joint. Aesthet Surg J. 2016;36:229-36

20. Hong Z, Chen J, Zhang S, Zhao C, Bi M, Chen X, et al. Intra-articular injection of autologous adipose-derived stromal vascular fractions for knee osteoarthritis: a double-blind randomized self-controlled trial. Int Orthop. 2019;43:1123-34.

21. Michalek J, Moster R, Lukac L, Proefrock K, Petrasovic M, Rybar J, et al. Comparative validation of the WOMAC osteoarthritis and Lequesne algofunctional indices in Greek patients with hip or knee osteoarthritis. Cell Transplant. 2015. https://doi.org/10.3727/096368915X686760. [Epub ahead of print].

22. Jo CH, Chai JW, Jeong EC, Oh S, Shin JS, Shim H, et al. Intra-articular injection of Mesenchymal stem cells for the treatment of osteoarthritis of the knee: a 2-year follow-up study. Am J Sports Med. 2017;45:2774-83.

23. Kijowski R, Blankenbaker DG, Munoz Del Rio A, Baer GS, Graf BK. Evaluation of the articular cartilage of the knee joint: value of adding a T2 mapping sequence to a routine MR imaging protocol. Radiology. 2013;267:503-13.

24. Ronga M, Angeretti G, Ferraro S, DE Falco G, Genovese EA, Cherubino P. Imaging of articular cartilage: current concepts. Joints. 2014;2:137-40.

25. Faul F, Erdfelder E, Buchner A, Lang AG. Statistical power analyses using G* power 3.1: tests for correlation and regression analyses. Behav Res Methods. 2009;41: 1149-60.

26. Bellamy, N. WOMAC osteoarthritis index user's guide (version X). Australia: Brisbane; 2012.

27. Knee Injury and Osteoarthritis Outcome Score. http://www.koos.nu/ 26 Dec 2019

\section{Publisher's Note}

Springer Nature remains neutral with regard to jurisdictional claims in published maps and institutional affiliations.

\section{Ready to submit your research? Choose BMC and benefit from:}

- fast, convenient online submission

- thorough peer review by experienced researchers in your field

- rapid publication on acceptance

- support for research data, including large and complex data types

- gold Open Access which fosters wider collaboration and increased citations

- maximum visibility for your research: over $100 \mathrm{M}$ website views per year

At BMC, research is always in progress.

Learn more biomedcentral.com/submissions 